\title{
Treatment of Coronary Artery Perforation and Tamponade Complicating Balloon Angioplasty by PTFE-Covered Stent. A Case Report
}

\author{
Jong Seon Park, Gu Ru Hong, Jun Ho Bae, Ihn Ho Cho*, \\ Bong Sup Shim, Young Jo Kim, Dong Gu Shin \\ Division of Cardiology, Department of Internal Medicine, \\ College of Medicine, Yeungnam University, Daegu, Korea \\ Department of Nuclear Medicine, College of Medicine, \\ Yeungnam University, Daegu, Korea*
}

- Abstract-

A coronary artery perforation is a rare but often fatal complication of angioplasty. We experienced a coronary artery perforation and cardiac tamponade during balloon angioplasty. A polytetrafluorethylene (PTFE)-covered stent was used to successfully close the perforation.

Key Words: Angioplasty, Coronary Stenosis, Rupture

INTRODUCTION

A perforation of the coronary arteries is a rare complication of percutaneous coronary intervention (PCI). However, it often progresses to a tamponade or myocardial infarction requiring emergency surgery, resulting in high mortality. ${ }^{1,2)}$ There are many therapeutic modalities available for treating a coronary artery perforation. A recently coated stent made from polytetrafluorethylene (PTFE) is useful for coronary aneurysms and perforations. Here, we report a case of a successful treatment of a coronary artery perforation complicating a balloon angioplasty using a PTFE-covered stent.

\section{CASE REPORT}

A 50-year-old male complained of increasing chest pain upon exertion over a 3-months periods. The physical examination revealed 
the blood pressure, heart rate and respiratory rate to be $110 / 70 \mathrm{mmHg}, 68$ beats/min, and 20 breaths/min, respectively. The heartbeat was regular without any murmur and the breathing sound was clear. A 12-lead electrocardiogram showed a normal sinus rhythm, left ventricular hypertrophy and a left bundle branch block. A Tc-99m MIBI myocardial perfusion scan with adenosine stress showed a perfusion defect at the apex and anterior wall of the left ventricle (LV), with the defect completely recovering after resting. The LV ejection fraction on the perfusion scan was 49\% at rest. The coronary angiography revealed a diffuse 60\% stenosis in the distal right coronary artery (RCA), an 80\% stenosis in the proximal left circumflex artery (LCX), minimal stenosis in the proximal left anterior descending coronary artery

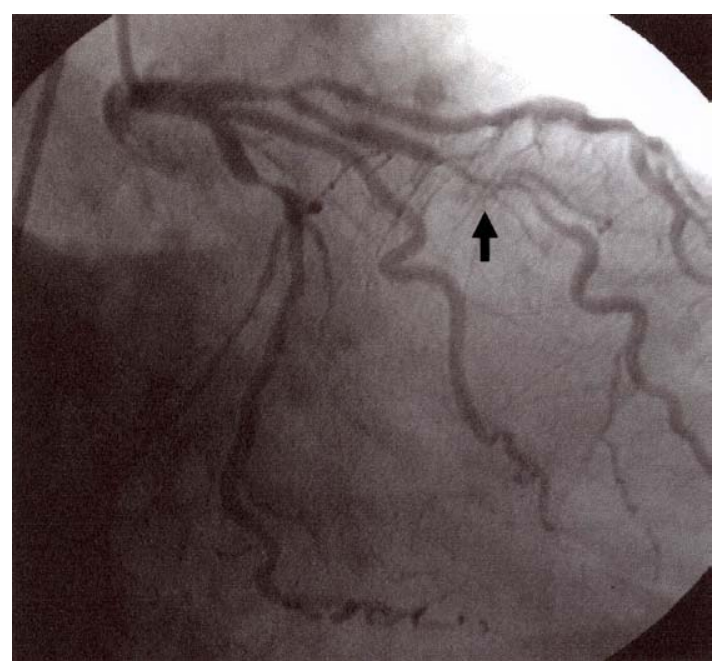

Fig. 1. Basal angiogram showing a tubular $80 \%$ stenosis at the 1st diagonal branch (arrow).
(LAD) with $80 \%$ stenosis at its neighboring 1st diagonal branch (DG), and a tubular stenosis $80 \%$ at the mid LAD (Fig. 1). The patient was referred for coronary angioplasty.

Coronary artery stenting with balloon dilatation was planned at the mid LAD, 1st diagonal branch and proximal LCX. Initially, coronary stenting was attempted at the 1st diagonal lesion. A 7 Fr JLA guiding catheter (Cordis, Miami, FL, USA) was positioned at the left main osteum. Two 0.014" ChoicePT guide wires (Boston Scientific, Boston) were advanced into the 1st diagonal branch and distal LAD. Two predilatations were performed at the 1st diagonal branch using a $2.5 \mathrm{~mm}$ U-pass balloon catheter (Cordis, Miami, FL, USA) which was to 8 and $10 \mathrm{~atm}$, respectively. After the second predilatation, the coronary angiography revealed pumping extravascular

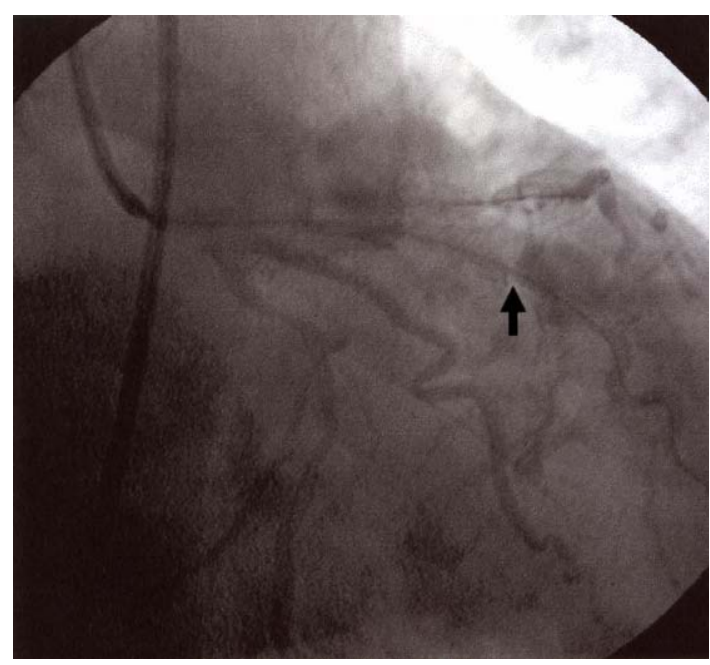

Fig. 2. Coronary angiogramy after balloon dilation showing pumping extravascular flow at the lesion site (arrow) and subsequent diffuse pericardial contrast. 
flow at the balloon dilatation site (Fig. 2). The patient complained of severe chest pain and his blood systolic pressure dropped to 80 mmHg. A balloon was inserted into the perforated lesion site and inflated again. Normal saline and dopamine was then infused intravenously and the systolic blood pressure maintained at $70-80 \mathrm{mmHg}$. Pericardiocentesis was then attempted under the guidance of echocardiography, but the guide wire passed through right ventricular wall and the catheter drainage failed. A decision was made to seal off the perforation site by implanting $3.0 \mathrm{~mm}$ in diameter and $19 \mathrm{~mm}$ in length PTFE-covered stent (JOMED, Sweden). The aneurysm was sealed off completely and the blood pressure

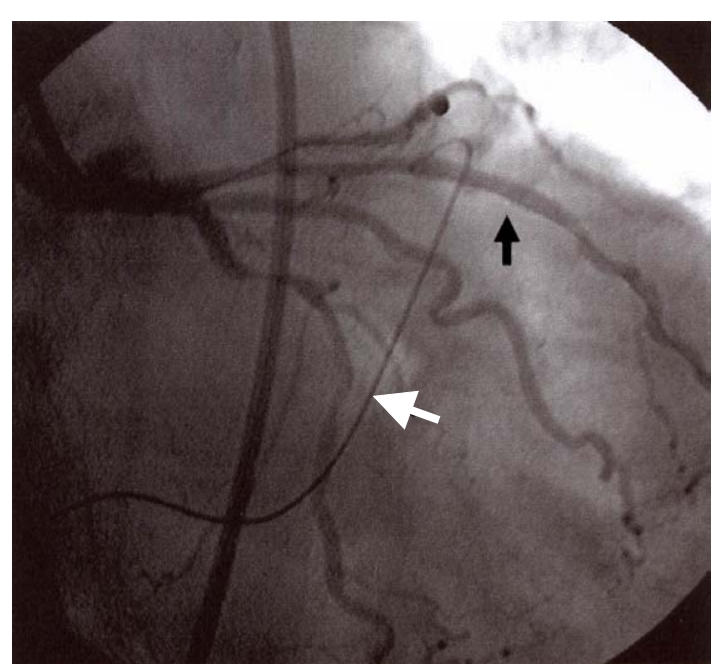

Fig. 3. Coronary angiogram after a stent-graft implantation demonstrating complete sealing of the perforation without any leakage (black arrow). The guide wire for a pericardiocentesis is in the right ventricular outflow tract (white arrow). returned to $100 / 70 \mathrm{mmHg}$ (Fig. 3). The patient underwent surgery to remove the blood collected in the pericardial space as well as the misplaced guide wire.

The patient was discharged with medications, such as aspirin $200 \mathrm{mg} /$ day and ticlopidine $500 \mathrm{mg} /$ day. After a 6 months follow up, there was no complaint of angina under the medications.

\section{DISCUSSION}

A rupture and perforation of the coronary arteries are a very rare complications associated with balloon angioplasty. However it can have serious consequences with a high mortality rate. The incidence varies depending on the type of procedures and has been reported range from $0.2 \%$ and $0.6 \%$. $^{1,2}$ Coronary artery perforation is more common after using a new devices (0.86\%) than after the balloon angioplasty $(0.41 \%)^{3)}$ ) It is more commonly observed in patients with a history of congestive heart failure, female patients and following the use of atheroablative interventional technologies $(2.8 \%)^{1,4)}$ In this case, the target lesion was quite hard and the balloon was displaced during inflation. The misplaced balloon might have caused the dissection and rupture of the plaque edge. Consequently, the balloon needs to be inflated carefully during angioplasty for a calcified, eccentric and hard lesion.

Many therapeutic modalities have been 
proposed for the treatment of a coronary perforation, but such treatments should be selected according to the type of perforation as well as the severity. An angiographic perforation class $^{-}$specific algorithm was proposed. ${ }^{4)}$ Intravenous heparin-neutralizing protamine sulfate is sufficient in most cases of a type I perforation, which is defined as epicardial staining without a jet of contrast extravasation. However, more intensive treatment is required for type II patients who have pericardial staining with a visible contrast jet with out patient. Severe and hemodynamically compromising perforations can also be treated with prolonged balloon inflation, coronary stenting, intracoronary autologous blood," coronary microcoil ${ }^{6)}$ and gelfoam embolization. ${ }^{7)}$ In cases of catastrophic perforations, as in our patient, various sealing devices, autologous vein cover stents ${ }^{8)}$ and
PTFE-coated stent ${ }^{2,9)}$ are useful (Fig. 4). A stent-graft is an effective treatment modality for a coronary pesudoaneurysm and perforation. $^{10-12)}$ Although covered stents are quite useful for sealing a ruptured coronary artery, the stents are usually bulky and the delivery of the stent-graft to the site of vessel rupture sometimes requires deep intubation of the guiding catheter. In addition, it must be used with caution in regions with significant side branching.

A cardiac tamponade is an uncommon but serious complication of a coronary perforation because the patient's hemodynamic status can worsen in a very short time and it is associated with a high mortality and morbidity. Most cases are recognized immediately but a delayed cardiac tamponade can occur. Therefore, this possibility needs to be considered when a patient suffers hypotension

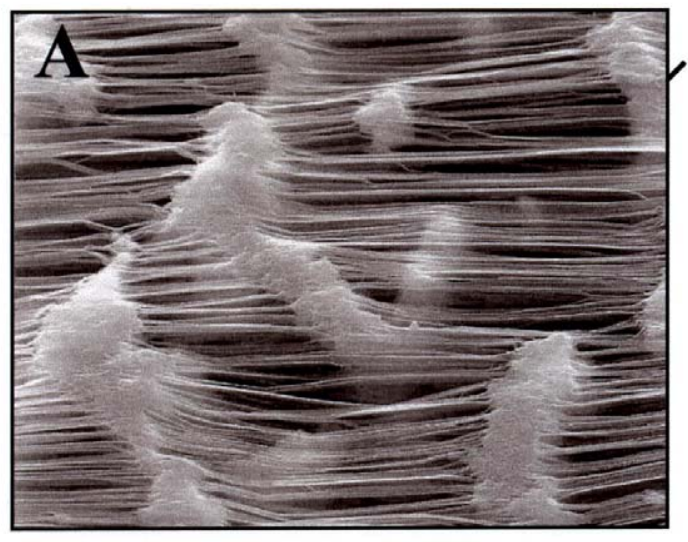

\section{$10 \mu \mathrm{m}$}

Fig. 4. Ultrastructure (A) and gross photograph (B) of the JOSTENT ${ }^{\circledR}$ coronary stent graft used in this patient. 
- Jong Seon Park, Gu Ru Hong, Jun Ho Bae, Ihn Ho Cho*, Bong Sup Shim, Young Jo Kim, Dong Gu Shin-

after a PCI. ${ }^{13)}$ In the case of a hemodynamically unstable patient, an immediate pericardiocentesis and pericardial catheter drainage are lifesaving procedures. ${ }^{14)}$ In our case, the immediate pericardiocentesis failed but the leak was stopped with immediate stent-graft implantation under the infusion of dopamine.

In conclusion, a coronary perforation during a percutaneous interventions can be treated effectively by implanting a stent-graft.

\section{요 약}

관상동맥파열은 중재시술시 간헐적으로 발 생하는 합병증이지만 급성 심장눌림증으로 진 행하여 치명적일 수 있다. 일반적으로 중재시 술시 사용하는 유도철선에 의한 천공은 자연방 누되는 경우가 많으나 본 예와 같이 풍선이나 죽상판 제거술 등으로 인한 천공은 매우 급격 히 진행하여 생명이 위험할 수 있다. 과거에는 젤라틴이나 자가혈전을 이용하여 파열된 부위 를 막거나 수술적 교정을 하였으나 시술이 매 우 복잡하고 시술지연에 따른 문제가 많이 발 생한다. 이식판 그물망은 동맥류의 치료를 위 해 개발되어 유용하게 이용되어 지고 있다. 본 예와 같이 관동맥 성형술 중에 관동맥이 천공 되어 위급한 경우에도 이식판 그물망은 유용한 치료법으로 이용될 수 있다.

\section{REFERENCES}

1. Gruberg L, Pinnow E, Flood R, Bonnet $\mathrm{Y}$, Tebeica M, Waksman $\mathrm{R}$, et al. Incidence, management, and outcome of coronary artery perforation during percutaneous coronary intervention. Am J Cardiol 2000 Sep 15;86(6): 680-2.

2. Bilge AK, Nisanci Y, Ozben B, Yilmaz E, Umman B. Coronary perforation and tamponade during thrombectomy and treatment with PTFE coated stent and autotransfusion: a case report. Anadolu Kardiyol Derg 2003 Jun;3(2):174-6.

3. Fukutomi T, Suzuki T, Popma JJ, Hosokawa H, Yokoya K, Inada T, et al. Early and late clinical outcomes following coronary perforation in patients undergoing percutaneous coronary intervention. Circ J 2002 Apr;66(4):349-56.

4. Dippel EJ, Kereiakes DJ, Tramuta DA, Broderick TM, Shimshak TM, Roth EM, et al. Coronary perforation during percutaneous coronary intervention in the era of abciximab platelet glycoprotein $\mathrm{Ilb} / \mathrm{III}$ blockade: an algorithm for percutaneous management. Catheter Cardiovasc Interv 2001 Mar;52(3): 279-86.

5. Cordero H, Gupta N, Underwood PL, Gogte ST, Heuser RR. Intracoronary autologous blood to seal a coronary perforation. Herz 2001 Mar;26(2):157-60.

6. Aslam MS, Messersmith RN, Gilbert J, Lakier JB. Successful management of coronary artery perforation with helical platinum microcoil embolization. Catheter Cardiovasc Interv 2000 Nov;51(3):320-2.

7. Dixon SR, Webster MW, Ormiston JA, Wattie WJ, Hammett CJ. Gelfoam embolization of a distal coronary artery guidewire perforation. Catheter Cardiovasc Interv 2000 Feb;49(2): 214-7.

8. Caputo RP, Amin N, Marvasti M, Wagner S, Levy C, Giambartolomei A. Successful treatment of a saphenous vein graft perforation with an autologous vein-covered stent. Catheter 
Cardiovasc Interv 1999 Dec;48(4):382-6.

9. Gyenes G, Lazzam C, Feindel C, Roth SL. Successful treatment of a saphenous vein graft pseudoaneurysm with PTFE-covered JoStents. Can J Cardiol 2003 Apr;19(5):569-71.

10. Antonellis IP, Patsilinakos SP, Pamboukas CA, Kranidis AJ, Prappa E, Filippatos G, et al. Sealing of coronary artery aneurysm by using a new stent graft. Catheter Cardiovasc Interv 1999 Sep;48(1):96-9.

11. Leung AW, Wong P, Wu CW, Tsui PT, Mok NS, Lau ST. Left main coronary artery aneurysm: sealing by stent graft and long-term follow-up. Catheter Cardiovasc Interv 2000 Oct:51(2):205-9.

12. Demin VV. Successful correction with stent- graft of coronary artery rupture after angioplasty. Angiol Sosud Khir 2003;9(2):118-21.

13. Fejka M, Dixon SR, Safian RD, O'Neill WW, Grines CL, Finta B, et al. Diagnosis, management, and clinical outcome of cardiac tamponade complicating percutaneous coronary intervention. Am J Cardiol 2002 Dec 1;90(11): 1183-6.

14. Altman F, Yazdanfar S, Wertheimer J, Ghosh S, Kotler M. Cardiac tamponade following perforation of the left anterior descending coronary system during percutaneous transluminal coronary angioplasty: successful treatment by pericardial drainage. Am Heart J 1986 Jun; 111(6):1196-7. 